\title{
Performance of Wheat (Triticum aestivum L.) under Varying Levels of Silicon and Restricted Irrigation
}

\author{
Rajaram Sharma, J. Choudhary ', D. Singh, S. C. Meena and Vijay Kumar \\ Department of Agronomy, Rajasthan College of Agriculture, Maharana Pratap University of \\ Agriculture and Technology, Udaipur (Rajasthan), India \\ *Corresponding author
}

\section{A B S T R A C T}

A field experiment was conducted during rabi season 2019-20 at Rajasthan College of Agriculture, MPUAT, Udaipur (Rajasthan), to evaluate the effect of different irrigation and silicon levels on wheat productivity. Results revealed that three irrigations given to

\section{Keywords}

Irrigation, Silicon,

Yield and

Economics

\section{Article Info}

Accepted:

04 October 2020

Available Online:

10 November 2020 wheat crop improved growth characters viz., plant height $(45.42,80.71 \mathrm{~cm})$ at 50 and 75 DAS, dry matter accumulation (27.49 g) at 50 DAS as compare to other treatments. Days to 50 per cent heading (73.25) and maturity (107.33) also increase with three irrigations but statistically non significant with two irrigations. Advanced performance of yield attributes with three irrigations resulted in significant increased in grain yield (4297 $\mathrm{kg} \mathrm{ha}^{-}$ ${ }^{1}$ ) and harvest index (38.92\%), it reflected economics of crop and the highest net return (₹ $67180 \mathrm{ha}^{-1}$ ) and B- C ratio (1.99) were obtained. Amongst different levels of silicon, $200 \mathrm{~kg} \mathrm{ha}^{-1}$ increased plant height, dry matter accumulation, days to 50 per cent heading and maturity but statistically non significant with $150 \mathrm{~kg} \mathrm{ha}^{-1}$.Increasing levels of silicon up to $200 \mathrm{~kg} \mathrm{ha}^{-1}$ also improved yield attributes i.e., effective tillers $(43.280 .5 \mathrm{~m}$ row length), grains ear ${ }^{-1}(42.75)$, weight of grains ear ${ }^{-1}(1.76 \mathrm{~g})$, ear length $(7.34 \mathrm{~cm})$ and test weight $(40.79 \mathrm{~g})$ compare to control. The maximum grain yield $\left(3824 \mathrm{~kg} \mathrm{ha}^{-1}\right)$, harvest index $(37.30 \%)$ and economics i.e., net return (₹ $58770 \mathrm{ha}^{-1}$ ) and $\mathrm{B}-\mathrm{C}$ ratio (1.79)were obtained under silicon $200 \mathrm{~kg} \mathrm{ha}^{-1}$ which was statistically at par with $150 \mathrm{~kg} \mathrm{ha}^{-1}$ but superior over rest of treatments.

\section{Introduction}

Wheat (Triticum aestivum L.) is universally known as 'King of cereals' because of its wider adaptability \& elevated productivity and such crop supply food in the form of groceries and nutrition for more than 60 per cent of the world's population. In India, it ranked second than rice in terms of its importance and role in food security. After green revolution (1965-66), this crop has been contributed significantly towards country' ssuccess in food sufficiency. In global level, wheat also ranked second after rice crop in food grain production and it was grown in 220.4 million hectare area with the production of 768.49 million tonnes (FAOSTAT, 2020).With respect to global wheat production, India stands second position after China. In India wheat grown on 30.55 million 
hectare area with production of 107.18 million tonnes and productivity $3508 \mathrm{~kg}$ ha ${ }^{1}$ In India, Rajasthan state takes fifth position in wheat production after Uttar Pradesh, Madhya Pradesh, Punjab and Haryana. In Rajasthan, it is cultivated in 3.20 million hectare area with the production of 10.57 million tonnes and having productivity of $3501 \mathrm{~kg} \mathrm{ha}^{-1}$ (IIWBR 2019-20).

Silicon ( $\mathrm{Si}$ ) is a chemical element having an atomic number of 14. It is a hard and brittle crystalline solid with a blue-grey metallic luster. Si is the second most abundant element both on surface of especially earth's crust and in the soil after oxygen. The earth's crust constitutes 27.72 per cent of silicon. The beneficial effects of $\mathrm{Si}$ are particularly distinct in plants exposed to abiotic and biotic stresses (Liang et al., 2007). Si can increase plants capabilities stand with water stress because it decreasing the rate of transpiration process. Transpiration from the leaves mainly occurs through the stomata and partly through the cuticle of the leaves forming a silicon-cuticle double layer, the transpiration through cuticle may decrease due to silica deposition (Ma, 2004).Excess accumulation of Si within plant and soil does not damage the plants and it will be required for healthy plant growth and stable production. For this reason, $\mathrm{Si}$ has been recognized as an "agronomically essential element" in Japan and silicate fertilizers have been applied to paddy soils (Ma et al., 2001).

Water given to the plants by artificial means is one of the very important practices to obtain higher productivity. Adequate soil moisture is required for proper development in terms of vegetative and reproductive growth of the plant. In India about 90 per cent area of wheat under irrigated conditions, generally four to six irrigations are required for maximizing wheat yield under clay- loam soil. Irrigation recommended for wheat crop in accordance to their critical stages are namely at crown root initiation (21 DAS), tillering stage (40-45 DAS), jointing (60-65 DAS), flowering (80-85 DAS), milking (100105 DAS) and dough stage (115-120 DAS). Irrigation given at crown root initiation stage is very important for successful growth of wheat and it has a great impact on higher grain yield (Randhawa et al., 2004). Water supplied at booting to heading stages promoted both spike and grain development (Zhang-Xucheng et al., 2011). Wheat yields are reduced by 50-90 per cent due to reduction of irrigation sources in the developing world (Devi et al., 2012).

\section{Materials and Methods}

The experiment was conducted during rabi season of 2019-20, at the Instructional Farm, Department of Agronomy, Rajasthan College of Agriculture, MPUAT, Udaipur, which is situated at $74^{\circ} 42^{\prime} \mathrm{E}$ longitude, $24^{\circ} 35^{\prime} \mathrm{N}$ latitude and 582.17 metre of height above mean sea level. The region falls under NARP agro-climatic zone IVa of Rajasthan i.e. SubHumid Southern Plains and Aravalli Hills. Udaipur zone possesses a typical sub-tropical climatic conditions characterized by mild winters and moderate summers associated with high relative humidity during the rainy season. The average rainfall of udaipur is 637 $\mathrm{mm}$, out of this (80-85\%) is received through south-west monsoon during July to early September.

The experimental site soil was clay-loam and $\mathrm{pH} \quad 7.75$ which was slightly alkaline. However, experimental soil was medium in organic carbon $(0.66 \%)$, available nitrogen (286.5 $\mathrm{kg} \mathrm{ha}^{-1}$ ) and available phosphorus (21.6kg ha-1). Whereas, availability of potassium in soil was high i.e., $369.7 \mathrm{~kg} \mathrm{ha}^{-1}$. The experiment was laid out in split plot with four irrigation levels ( $\mathrm{I}_{1}$ : no irrigation, $\mathrm{I}_{2}$ : one irrigation at $\mathrm{CRI}, \mathrm{I}_{3}$ : two irrigation at $\mathrm{CRI}$ and booting stage and $\mathrm{I}_{4}$ : three irrigation at CRI, 
booting and milking stage) and four silicon levels $\left(S_{1}\right.$ : control, $S_{2}: 100 \mathrm{~kg} \mathrm{ha}^{-1}, \mathrm{~S}_{3}: 150 \mathrm{~kg}$

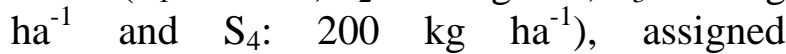
respectively to main and sub plots and those were replicated three times. The seed rate of wheat was $100 \mathrm{~kg} \mathrm{ha}^{-1}$ seed.

The wheat variety "MP 3336" was sown during second week of November. The recommended dose of nitrogen, phosphorous and potash was $90 \quad-60-40 \quad \mathrm{~kg} \mathrm{ha}^{-1}$, respectively, which was applied through urea, DAP and MOP. During the season one third quantity of total nitrogen and whole amount of phosphorous and potash were applied as basal at sowing, while remaining quantity of nitrogen was applied in two split of equal quantity at first and second irrigation.

For total dry matter accumulation, plant samples were oven dried at the temperature of $70^{\circ} \mathrm{C}$ to achieve constant weight. Thereafter, the samples were weighed for computing the dry weight $(\mathrm{g})$ of plants $\left(0.5 \mathrm{~m}^{-1}\right.$ row length). The yield attributes were estimated by selecting five plants form each experimental plot, leaving the two border rows on the rows direction and half metre on opposite direction of the plot of wheat. Were harvested manually with stickles.

The produce was kept for sun drying in field for some days and after drying the biological yield was recorded and expressed in $\mathrm{kg} \mathrm{ha}^{-1}$. After threshing the bundles from each plot, the grains were cleaned, dried and weighed. The grain yield was expressed in $\mathrm{kg} \mathrm{ha}^{-1}$.

Harvest index was calculated by dividing the economic yield (grain yield) to the biological yield and expressed in percentage as suggested by Donald and Hamblin (1976).

$$
\text { Harvest Index }(\%)=\frac{\text { Grain yield }}{\text { Biological yield }} \times 100
$$

\section{Results and Discussion}

\section{Growth}

Irrigation levels had significant effect on plant height, dry matter accumulation at 50 to 75 DAS and days to 50 per cent heading and maturity (Table 1). The maximum plant height was recorded at 50 DAS $(45.42 \mathrm{~cm})$ and at 75 DAS $(80.71 \mathrm{~cm})$ was recorded under three irrigations which was statistically at par with one and two irrigations bur significantly superior over the control. The maximum dry matter accumulation at 50 DAS $(27.49 \mathrm{~g})$ had recorded under three irrigations which was statistically at par with one and two irrigations but statistically higher over control. At 75 DAS the highest dry matter accumulation (74.83 g) was recorded under two irrigations, it was statistically at par with one and three irrigations but significantly superior over control. The maximum days to 50 per cent heading (73.25) and maturity (107.33) was recorded under three irrigations, it was statistically at par with two irrigations but significantly superior over control and one irrigation, respectively. Water is an elementary constituent of plant protoplasm and their adequate supplies enhance cell division and as well as cell elongation. Therefore, optimum availability of water with three irrigations to wheat might have improved the photosynthetic area of plants that cumulatively contributed to higher plant height and dry matter accumulation. The result of this study are in close conformity by Kharrou et al., (2011), Sarwar et al., (2010) and Mer et al., (2014).

The application of silicon $200 \mathrm{~kg} \mathrm{ha}^{-1}$ was recorded the maximum plant height (43.75, $76.18 \mathrm{~cm})$ and dry matter accumulation $(25.38,72.42 \mathrm{~g})$ at 50 to $75 \mathrm{DAS}$, which was statistically at par with silicon $150 \mathrm{~kg} \mathrm{ha}^{-1}$ and silicon $100 \mathrm{~kg} \mathrm{ha}^{-1}$ but significantly superior over the control (Table 1). 
Table.1 Effect of irrigation and silicon levels on plant height, dry matter accumulation (g) and days to 50 per cent heading

\begin{tabular}{|c|c|c|c|c|c|c|}
\hline \multirow[t]{2}{*}{ Treatments } & \multicolumn{2}{|c|}{ Plant height (cm) } & \multicolumn{2}{|c|}{ Dry matter accumulation (g) } & \multirow[t]{2}{*}{ Days to $50 \%$ heading } & \multirow[t]{2}{*}{ Days to $50 \%$ maturity } \\
\hline & 50 DAS & 75 DAS & 50 DAS & 75 DAS & & \\
\hline \multicolumn{7}{|l|}{ Irrigation levels } \\
\hline No irrigation & 33.22 & 61.50 & 18.76 & 55.92 & 61.50 & 91.17 \\
\hline One irrigation & 43.54 & 71.08 & 25.28 & 73.83 & 71.08 & 99.58 \\
\hline Two irrigation & 45.02 & 72.58 & 26.46 & 74.83 & 72.58 & 104.00 \\
\hline Three irrigation & 45.42 & 73.25 & 27.49 & 74.25 & 73.25 & 107.33 \\
\hline SEm \pm & 0.91 & 0.48 & 0.73 & 1.77 & 0.48 & 1.22 \\
\hline $\mathrm{CD}(\mathrm{P}=\mathbf{0 . 0 5})$ & 3.15 & 1.65 & 2.52 & 6.12 & 1.65 & 4.23 \\
\hline \multicolumn{7}{|l|}{ Silicon levels } \\
\hline Control & 39.50 & 67.75 & 23.09 & 65.33 & 67.75 & 99.58 \\
\hline $100 \mathrm{~kg} \mathrm{ha}^{-1}$ & 41.78 & 69.17 & 24.45 & 69.83 & 69.17 & 99.17 \\
\hline $150 \mathrm{~kg} \mathrm{ha}^{-1}$ & 42.17 & 70.42 & 25.07 & 71.25 & 70.42 & 101.50 \\
\hline $200 \mathrm{~kg} \mathrm{ha}^{-1}$ & 43.75 & 71.08 & 25.38 & 72.42 & 71.08 & 101.83 \\
\hline SEm \pm & 0.60 & 0.33 & 0.56 & 1.74 & 0.33 & 0.78 \\
\hline $\mathrm{CD}(\mathrm{P}=0.05)$ & 1.74 & 0.96 & 1.63 & 5.08 & 0.96 & NS \\
\hline
\end{tabular}

Table.2 Effect of irrigation and silicon levels on yield attributes of wheat crop

\begin{tabular}{|c|c|c|c|c|c|}
\hline \multirow[t]{2}{*}{ Treatments } & \multicolumn{5}{|c|}{ Yield attributes } \\
\hline & $\begin{array}{c}\text { Effective tillers }(0.5 \\
\text { m row length) }\end{array}$ & Grains ear $^{-1}$ & $\begin{array}{c}\text { Weight of grains ear }{ }^{-1} \\
\text { (g) }\end{array}$ & $\begin{array}{l}\text { Ear length } \\
\quad(\mathrm{cm})\end{array}$ & Test weight \\
\hline \multicolumn{6}{|l|}{ Irrigation levels } \\
\hline No irrigation & 31.14 & 33.25 & 1.28 & 6.65 & 37.33 \\
\hline One irrigation & 43.33 & 42.25 & 1.67 & 7.15 & 39.54 \\
\hline Two irrigation & 45.09 & 43.33 & 1.78 & 7.38 & 41.04 \\
\hline Three irrigation & 47.46 & 44.92 & 1.88 & 7.69 & 41.89 \\
\hline SEm \pm & 0.67 & 0.78 & 0.03 & 0.20 & 0.49 \\
\hline $\mathrm{CD}(\mathrm{P}=0.05)$ & 2.33 & 2.69 & 0.09 & 0.67 & 1.70 \\
\hline \multicolumn{6}{|l|}{ Silicon levels } \\
\hline Control & 39.77 & 39.83 & 1.54 & 7.18 & 38.12 \\
\hline $100 \mathrm{~kg} \mathrm{ha}^{-1}$ & 41.33 & 40.33 & 1.64 & 7.20 & 40.35 \\
\hline $150 \mathrm{~kg} \mathrm{ha}^{-1}$ & 42.66 & 40.83 & 1.67 & 7.15 & 40.55 \\
\hline $200 \mathrm{~kg} \mathrm{ha}^{-1}$ & 43.28 & 42.75 & 1.76 & 7.34 & 40.79 \\
\hline SEm \pm & 0.59 & 0.57 & 0.02 & 0.12 & 0.39 \\
\hline $\mathrm{CD}(\mathrm{P}=0.05)$ & 1.73 & 1.66 & 0.07 & NS & 1.15 \\
\hline
\end{tabular}


Table.3 Effect of irrigation and silicon levels on grain yield, harvest index and economics

\begin{tabular}{|c|c|c|c|c|}
\hline \multirow[t]{2}{*}{ Treatments } & \multirow[t]{2}{*}{ Grain yield (kg ha $\left.{ }^{-1}\right)$} & \multirow[t]{2}{*}{ Harvest index (\%) } & \multicolumn{2}{|c|}{ Economics } \\
\hline & & & Net return (₹ ha $\left.{ }^{-1}\right)$ & B- C ratio \\
\hline \multicolumn{5}{|l|}{ Irrigation levels } \\
\hline No irrigation & 2195 & 32.37 & 26066 & 0.88 \\
\hline One irrigation & 3398 & 34.80 & 52529 & 1.70 \\
\hline Two irrigation & 3860 & 35.91 & 61241 & 1.89 \\
\hline Three irrigation & 4297 & 38.92 & 67180 & 1.99 \\
\hline SEm \pm & 94.74 & 0.94 & 1526.30 & 0.05 \\
\hline $\mathrm{CD}(\mathrm{P}=\mathbf{0 . 0 5})$ & 327.84 & 3.25 & 5281.71 & 0.17 \\
\hline \multicolumn{5}{|l|}{ Silicon levels } \\
\hline Control & 3004 & 33.39 & 43959 & 1.43 \\
\hline $100 \mathrm{~kg} \mathrm{ha}^{-1}$ & 3262 & 34.81 & 48345 & 1.52 \\
\hline $150 \mathrm{~kg} \mathrm{ha}^{-1}$ & 3659 & 36.50 & 55942 & 1.73 \\
\hline $200 \mathrm{~kg} \mathrm{ha}^{-1}$ & 3824 & 37.30 & 58770 & 1.79 \\
\hline SEm \pm & 88.43 & 0.66 & 1601.06 & 0.05 \\
\hline $\mathrm{CD}(\mathrm{P}=0.05)$ & 258.10 & 1.93 & 4673.17 & 0.15 \\
\hline
\end{tabular}


The maximum days to 50 per cent heading (71.08) was obtained with application of silicon $200 \mathrm{~kg} \mathrm{ha}^{-1}$, which was statistically at par with silicon $150 \mathrm{~kg} \mathrm{ha}^{-1}$ and but significantly superior over the control and silicon $100 \mathrm{~kg} \mathrm{ha}^{-1}$. Days to 50 per cent maturity was found non-significant due to different doses of silicon. Different studies have shown that silicon application affects crop growth, plant metabolism and physiology. In terms of plant height, deposition of silicon in cell wall can make the leaves and stems more erect and increase plant height even under drought conditions. Increase plant height can be attributed towards increased cell division and elongation caused by silicon. This finding is supported by Abro et al., (2009), Ma (2004) and Jaleel et al., (2009).

\section{Yield attributes}

The analysis of variance of data indicated that irrigation levels had significant effect on yield attributes of wheat viz., number of effective tillers ( $0.5 \mathrm{~m}$ row length), grains ear ${ }^{-1}$, weight of grains ear ${ }^{-1}(\mathrm{~g})$, ear length $(\mathrm{cm})$ and test weight (g) (Table 2). The maximum number of effective tillers (47.46), grains ear $^{-1}$ (44.92), weight of grains ear $^{-1}$ (1.88), ear length $(7.69 \mathrm{~cm})$ and test weight $(41.89 \mathrm{~g})$ were registered under three irrigations. Whereas minimum number of effective tillers (31.14), grains ear ${ }^{-1}$ (33.25), weight of grains ear $^{-1}(1.28)$, ear length $(6.65 \mathrm{~cm})$ and test weight $(37.33 \mathrm{~g})$ were registered under no irrigation. The application of three irrigations to wheat crop facilitates sufficient soil moisture for higher growth and development of the plants which enhanced photosynthetic efficiency by improving source-sink relationship of the plants leading higher growth and development reflected by higher yield attributes of plants. These findings were in accordance with Mubeen et al., (2013) and Ali et al., (2012).
The application of silicon $200 \mathrm{~kg} \mathrm{ha}^{-1}$ was recorded the maximum number of effective tillers $0.5 \mathrm{~m}$ row length (43.28), grains ear ${ }^{-1}$ (42.75), weight of grains ear $^{-1}(1.76 \mathrm{~g})$ and test weight (40.79 g) compare to other silicon levels. The application of silicon $200 \mathrm{~kg} \mathrm{ha}^{-1}$ enhanced the number of effective tillers by 9.43, 1.54 per cent, grains ear ${ }^{-1} 7.33,6.00$ per cent, weight of grains ear ${ }^{-1} 14.28,7.31$ per cent and test weight 7.00, 1.09 per cent over control and silicon $100 \mathrm{~kg} \mathrm{ha}^{-1}$.Ear length was not significantly affected owing of different silicon doses (Table 2)Silicon had many positive effects on the plant physiology and metabolism of the crop. Increase in yield attributes of wheat due to silicon application might be due to higher photosynthetic activity of plant, much more uptake of nutrients resulted enhance carbohydrate. Gholami and Falah, (2013) Wattanapayapkul et al., (2011) have confirmed the similar findings.

\section{Yield}

The grain yield of wheat was influenced significantly by various levels of irrigation (Table 3). Grain yield increased significantly with increase in number of irrigations. The maximum grain yield $\left(4297 \mathrm{~kg} \mathrm{ha}^{-1}\right)$ of wheat was recorded with three irrigations, which was significantly superior over control one and two irrigations. The magnitude of increase in grain yield with application of three irrigations was 95.76, 26.45 and 11.32 per cent over control, one and two irrigations, respectively. The maximum harvest index recorded $(38.92 \%)$ with the three irrigations, it was statistically at par with two irrigations but significantly superior over control and one irrigation. The magnitudes of increase in B-C ratio with application three irrigations were 20.23 and 11.83 per cent over control and one irrigation, respectively. The higher grain yield and harvest index of wheat with three irrigations attributed can be to advance photosynthetic activity of plants owing to 
optimum soil moisture for all the metabolic activities which leads to greater cell division, elongation resulted improve plant growth and development.

These results are in conformity with the findings of Yadav et al., (2010) and Rahim et al., (2010).

In case of silicon the maximum grain yield (3824 kg ha-1) and harvest index (37.30\%) were recorded under application of silicon $200 \mathrm{~kg} \mathrm{ha}^{-1}$, it was statistically at par with silicon $150 \mathrm{~kg} \mathrm{ha}^{-1}$ but significantly superior over control and silicon $100 \mathrm{~kg} \mathrm{ha}^{-1}$. The increase in grain yield and harvest index of wheat might be attributed to the increase in growth and yield characteristics of wheat and also to the stimulating effect of silicon in reducing biotic and abiotic stress. Silicon application may enhance crop yield by several indirect action such as decreased shading due to greater leaf erectness. Erectness of leaves as a result of silicon fertilization could account for about 10 per cent in the photosynthesis, thereby indirectly increasing yield. Similar results were also noticed by Marschner et al., (1988), Ma and Takahashi (1993) and Sorrato et al., (2012).

\section{Economics}

Among the different irrigation levels, the maximum net return ( $₹ 67180 \mathrm{ha}^{-1}$ ) and B-C ratio (1.99) were recorded with the application of three irrigations. Whereas minimum value of net return ( $₹ 26066 \mathrm{ha}^{-1}$ ) and B-C ratio (0.97). The higher crop productivity might be the principal reason for higher net returns with application of three irrigations compared to other treatments. Similar results of higher farm profitability were also reported by Parihar et al., (2003).

Application of silicon200 $\mathrm{kg} \mathrm{ha}$ was recorded maximum net return (₹ $58770 \mathrm{ha}^{-1}$ ) and $\mathrm{B}-\mathrm{C}$ ratio (1.79), it was at par with silicon $150 \mathrm{~kg} \mathrm{ha}^{-1}$ but statistically higher over silicon $100 \mathrm{~kg} \mathrm{ha}^{-1}$ and control. Silicon might be improve crop growth and yield characters along with make active photosynthetic activities and source- sink relationship which directly govern yield of crop (Table 3). Similar findings were observed by Sorrato et al., (2012).

On the basis of one year investigation, it can be concluded that, maximum grain yield (4297 kg ha ${ }^{-1}$ ), net return ( $₹ 67180 \mathrm{ha}^{-1}$ ) and B- C ratio (1.99) was obtained with three irrigation levels and in case of silicon application maximum grain yield (3824 $\mathrm{kg} \mathrm{ha}^{-1}$ ), net return (₹ $58770 \mathrm{ha}^{-1}$ ) and B- C ratio (1.79) was recorded under $200 \mathrm{~kg} \mathrm{ha}^{-1}$ compared to other treatments. However, B-C ratio was statistically at par in two and three irrigation levels and silicon doses viz., 200 and $150 \mathrm{~kg} \mathrm{ha}^{-1}$ and also remained non significant with each other. Hence, two irrigations with the application of $150 \mathrm{~kg} \mathrm{ha}^{-1}$ silicon were proved economically viable in wheat crop under restricted irrigation conditions.

\section{References}

Abro, S.A., Qureshi, R., Soomro, F.M., Ahmed, A.M. and Jakhar, G.S. 2009. Effects of silicon levels on growth and yield of wheat in silty loam soil. Pakistan Journal of Botany 41(3): 1385-1390.

Devi, R., Kaur, N. and Gupta, A.K. 2012. Potential of anti-oxidant enzymes in depicting drought tolerance of wheat. Indian Journal of Biochemistry and Biophysics 49: 257-265.

Donald, C.M. and Hamblin, J. 1976. The biological yield and harvest index of cereals as agronomist and plant breeding criteria. Advance Agronomy28: 361-404. 
FAOSTAT (Food and Agriculture Organization Statistics). 2020. Crops harvested. Food and Agricultural Organization Statistical Service(http://www.fao.org/faostat/en/ \#home; retrieved on dated 12-10-2020)

Gholami, Y. and Falah, A. 2013. Effects of two different sources of silicon on dry matter production, yield and yield components of rice, tarom hashemi variety and 843 lines. International Journal of Agriculture and Crop Sciences 5(3): 227-231.

IIWBR, Director's report, AICRP on Wheat and Barley. 2019-20. Improved technologies for higher income of farmers. Indian Institute of Wheat and Barley Research, Karnal (Haryana). pp- 02.

Jaleel, C.A., Manivannan, P., Wahid, A., Farooq, M., Al-Juburi, H.J., Somasundaram, R. and Panneerselvam, R. 2009. Drought stress in plants a review on morphological characteristics and pigments composition. International Journal Agriculture and Biology 11(1): 100-105.

Kharrou H, Er-Raki S, Chehbouni A, Duchemin B, Simonneaux V, LePage M, Ouzine L and Jarlan L. 2011. Water use efficiency and yield of winter wheat under different irrigation regimes in a semi-arid region. Agricultural Sciences 2: 273-82.

Liang, Y., Sun, W., Zhu, Y. and Christe, P. 2007. Mechanisms of silicon-mediated alleviation of abiotic stresses in higher plants. Environmental Pollution, 147(2): 422-428.

Ma, J.F. 2004. Role of silicon in enhancing the resistance of plants to biotic and abiotic stresses. Soil Science and Plant Nutrition, 50(1): 11-18.

Ma, J.F. 2004. Role of silicon in enhancing the resistance of plants to biotic and abiotic stresses. Soil Science and Plant Nutrition50(1): 11-18

Ma, J.F. and Takahashi, E. 1993. Interaction between calcium and silicon in watercultured rice plants. Plant and Soil148(1): 107-113.

Ma, J.F., Miyake, Y. and Takahashi, E. 2001. Silicon as a beneficial element for crop plants. Studies in Plant Science Elsevier 8: 17-39.

Marschner, H., Rimmington, G. 1988 Mineral nutrition of higher plants. Plant Cell Environment 11: 147-148.

Mer, M. and Ama, E.E. 2014. Effect of different irrigation regime on grain yield and quality of some Egyptian bread wheat cultivars. Journal of Agriculture Food and Applied Science 2(9): 275-282.

Parihar S. S. and Tiwari R. B. 2003. Effect of irrigation and nitrogen level on yield, nutrient uptake and water use of late sown wheat (Triticum aestivum). Indian Journal of Agronomy 48(2): 103-7.

Rahim R, Rahamtullah M A and Waraich A E. 2010. Effect of phosphorus application and irrigation scheduling on wheat yield and phosphorus use efficiency. Plant, Soil and Environment 29(1): 15-22.

Randhawa, A.S. Jolly, R. S and Arora, B. S. 2004. The effect of sowing time and rates and time of nitrogen application on dwarf wheat. Journal Research Punjab Agriculture University, 13(2): 130-135.

Sarwar, N., Maqsood, M., Mubeen, K., Shehzad, M., Bhullar, M.S., Qamar, R. and Akbar, N. 2010. Effect of different levels of irrigation on yield and yield components of wheat cultivars. Pakistan Journal of Agricultural Sciences 47(3): 371-374.

Soratto, R.P., Crusciol, C.A.C., Castro, G.S.A., Costa, C.H.M.D. and Ferrari 
Neto, J. 2012. Leaf application of silicic acid to white oat and wheat. Revista Brasileira de Ciencia do Solo, 36(5): 1538-1544.

Wattanapayapkul, W., Polthanee, A., Siri, B., Bhadalung, N.N. and Promkhambut, A.2011. Effects of silicon in suppressing blast disease and increasing grain yield of organic rice in North- East Thailand. Asian Journal of Plant Pathology 5(4): 134-145.

Yadav, S. A, Verma, A. S. and Verma, S. K. 2010. Productivity, nutrient uptake and water use efficiency of wheat (Triticum aestivum L.) under different irrigation levels and fertility sources. Indian Journal of Ecology 37(1): 13-7. Zhang-XuCheng, Zhu-Runshen, Xia-FangQin and Shangguan-ZhouPing 2011 Effects of irrigation at the critical growth stages of spring wheat plants and the period of severe drought in the hilly loess plateau of middle Gansu province, Shaanxi, China. Journal of Triticeae Crops, 26(5): 74-78.

\section{How to cite this article:}

Rajaram Sharma, J. Choudhary' D. Singh, S. C. Meena and Vijay Kumar. 2020. Performance of Wheat (Triticum aestivum L.) under Varying Levels of Silicon and Restricted Irrigation. Int.J.Curr.Microbiol.App.Sci. 9(11): 285-293. doi: https://doi.org/10.20546/ijcmas.2020.911.034 